\title{
Pengaruh Dekok Daun Sirih (Piper betle L) sebagai Bahan Teat Dipping pada Sapi Perah Friesian Holstein
}

\section{Effect of Green Betel Leaf Decoction (Piper betle L) as Teat Dipping Material on Friesian Holstein Cattle}

\author{
D. Atam ${ }^{1}$, N. Widjaya ${ }^{1}$, H. Permana ${ }^{1}$, T. Akhdiat ${ }^{1}$, dan R. F. Christi ${ }^{2 *}$ \\ ${ }^{1}$ Program Studi Peternakan, Fakultas Pertanian, Universitas Bandung Raya - Indonesia \\ ${ }^{2}$ Laboratorium Produksi Ternak Perah, Program Studi Peternakan, Universitas Padjadjaran, Bandung - \\ Indonesia \\ *Corresponding E-mail: radenfebrianto92@gmail.com \\ (Diterima: 8 Agustus 2019; Disetujui: 21 Maret 2020)
}

\begin{abstract}
ABSTRAK
Daun sirih merupakan tanaman herbal yang banyak manfaat dan memiliki antibakteri yang baik. Penelitian ini bertujuan mengetahui penggunaan dekok daun sirih hijau (Piper betle L.) sebagai bahan teat dipping terhadap persentase penurunan CMT dan TPC susu sapi FH laktasi 1, 2 dan 3 serta tingkat penggunaan dekok daun sirih hijau (Piper betle L.) yang dapat menurunkan jumlah bakteri paling tinggi dan mengurangi tingkat kejadian mastitis. Ternak penelitian adalah 36 ekor induk sapi perah Friesian Holstein $(\mathrm{FH})$ laktasi 1, 2 dan 3. Metode penelitian menggunakan eksperimental dengan rancangan acak lengkap faktorial yang terdiri atas 12 perlakuan dan masing-masing diulang sebanyak 3 kali . Hasil penelitian menunjukkan bahwa perlakuan berpengaruh sangat nyata $(\mathrm{P}<0,01)$ terhadap California Mastitis Test (CMT) dan Total Plate Count (TPC). Kesimpulan menunjukkan bahwa perlakuan dekok daun sirih $50 \%$ dan $60 \%$ menghasilkan paling efektif terhadap penurunan persentase CMT dan TPC, serta periode laktasi tidak mempengaruhi dalam penurunan persentase CMT dan TPC.
\end{abstract}

Kata kunci: dekok daun sirih, teat dipping, Callifornia Mastitis Test, Total Plate Count, sapi FH

\section{ABSTRACT}

Betel leaf is an herbal plant that has many benefits and has good antibacterial properties. This study aims to determine the use of green betel leaf decoction (Piper betle L.) as a teat dipping ingredient to the percentage of CMT and TPC reduction in lactating FH cow milk 1, 2 and 3 and the level of use of green betel leaf decoction (Piper betle L.) which can reduce the highest number of bacteria and reduce the incidence of mastitis. The research animals were 36 Holstein lactation-efficient dairy cows 1, 2, and 3. The research method used was an experimental design with a factorial, completely randomized design consisting of 12 treatments, and each was repeated three times. The results showed that the treatment had a very significant effect $(P<0.01)$ on the California Mastitis Test $(C M T)$ and Total Plate Count $(T P C)$. The conclusion shows that $50 \%$ and $60 \%$ betel leaf decoction treatment is the most effective against the reduction in the percentage of CMT and TPC, and the lactation period does not affect the decrease in the percentage of CMT and TPC.

Keywords: betel leaf decoction, teat dipping, California Mastitis Test, Total Plate Count, FH Cows

\section{PENDAHULUAN}

Sebagian besar peternak sapi perah rakyat belum memperhatikan manajemen kebersihan kandang dan lingkungannya dengan baik, sehingga bisa terjadi pada sapi perahnya terjangkit penyakit mastitis atau radang ambing. Setelah selesai proses pemerahan saluran susu pada puting akan tetap terbuka selama beberapa saat sehingga kuman 
atau bakteri memiliki kesempatan lebih mudah masuk ke dalam ambing dan menyebabkan radang ambing. Oleh karena itu, perlu dilakukan pencelupan puting menggunakan antiseptik untuk mencegah masuknya bibit penyakit yang dapat menyebabkan mastitis atau peradangan pada ambing.

Mastitis adalah suatu penyakit radang ambing yang disebabkan infeksi bakteri yang menyerang sel-sel kelenjar susu. Jenis mastitis digolongkan menjadi mastitis klinis dan mastitis subklinis. Mastitis klinis merupakan mastitis dengan tanda-tanda yang dapat dilihat jelas secara kasat mata seperti susu dengan gumpalan, susu berlendir, puting yang terinfeksi terasa panas, bengkak dan sensitif saat disentuh. Mastitis subklinis adalah radang ambing yang tidak dapat dilihat secara kasat mata, dan hanya bisa diamati melalui penggunaan alat bantu deteksi mastitis subklinis seperti uji California Mastitis Test (CMT). Mikroorganisme patogen seperti Staphylococcus aureus, Streptococcus agalactiae, Klebsiella spp, E. coli dan Corynebacterium bovis merupakan penyebab mastitis subklinis. Salah satu cara umum yang digunakan untuk mendeteksi mastitis subklinis adalah dengan menggunakan paddle dan reagent CMT yang disebut dengan California Mastitis Test (CMT) (Surjowardojo, 2011). Utami et al. (2014) melaporkan, prevalensi kasus mastitis subklinis di Jawa Barat, Jawa Tengah, Jawa Timur, dan Daerah Istimewa Yogyakarta antara 37\%-67\%, dan mastitis klinis antara 5\%-30\%. Mastitis subklinis pada sapi menyebabkan jeleknya kualitas susu yang dihasilkan, sehingga sangat merugikan peternak.

Teat dipping merupakan salah satu teknis meminimalisir kasus mastitis dengan cara mencelupkan puting sapi setelah pemerahan ke dalam cairan antiseptik selama beberapa saat. Teat dipping pasca pemerahan banyak dilakukan dan telah diterima secara luas sebagai salah satu perlakuan mengurangi kasus infeksi kelenjar susu. Iodium umumnya digunakan sebagai desinfektan untuk celup puting.
Saat ini terjadi kekhawatiran di sebagian masyarakat terhadap bahaya residu senyawa kimia pada bahan pangan yang dikonsumsi. Praktek teat dipping menggunakan iodium, atau senyawa kimiawi desinfektan lain dipandang bisa berakibat akumulasi residu di sekitar puting, dan akan terbawa ke dalam susu. Jika susu tercemar ini dikonsumsi akan berpengaruh terhadap keberadaan mikroorganisme di sepanjang saluran pencernaan konsumen, sehingga kemampuan dan efektivitas kinerja metabolismenya terganggu (Yusuf, 2010). Berdasarkan latar belakang inilah muncul gagasan memanfaatkan dekok daun sirih hijau sebagai bahan herbal untuk keperluan desinfeksi pada proses teat dipping. Hasil penelitian menunjukkan adanya beberapa senyawa aktif terkandung di dalam daun sirih. minyak atsiri, berfungsi sebagai antibakteri karena memiliki kemampuan menghambat pertumbuhan bakteri termasuk bakteri penyebab mastitis. Pemanfaatan daun sirih yang tumbuh di sekitar rumahpun dapat menekan biaya operasional peternakan sapi perah. Hal ini menjadi tolak ukur memanfaatkan dekok daun sirih hijau (Piper betle L.) sebagai cairan antiseptik teat dipping pada puting sapi terkait usaha menurunkan kejadian mastitis dan jumlah bakteri (TPC).

\section{METODE}

\section{Metode}

Materi yang digunakan adalah 36 ekor induk sapi perah Friesian Holstein yang terdiri atas periode laktasi 1, laktasi 2, dan laktasi 3, daun sirih hijau, air mineral, Teat Dipping, sabun cair, dekok daun sirih untuk bahan teat dipping, air bersih, reagent $\mathrm{CMT}$, susu, alkohol 70\%, Total Plate Count Plate Count Agar (media biakan), dan Buffered Pepton Water $0,1 \%$. Peralatan yang digunakan antara lain kompor, panci, stopwatch, gelas ukur kapasitas 1 liter, timbangan digital kapasitas $5 \mathrm{~kg}$ dengan ketelitian 0,01 gram, saringan, pisau, botol kapasitas 1 liter, corong, batang pengaduk, thermometer air, kertas 
saring, blander, teat dipping, tisue, botol celup putting, satu buah paddle CMT, alat tulis, tabung reaksi sebanyak 216 buah, rak tabung reaksi, mikro pipet, finntip, inkubator, waterbath, stomacher, colony counter, bunsen, marker, masker, hairnet, dan korek api untuk menyalakan bunsen.

\section{Metode Penelitian}

Pembuatan dekok daun sirih mengikuti prosedur Kurniawan et al. (2013) sebagai berikut: daun sirih dicuci menggunakan air mengalir sampai bersih, kemudian dianginanginkan sampai kering. Daun sirih yang sudah kering kemudian dicincang kasar. Irisan daun sirih dimasukan kedalam blander untuk dihaluskan dengan perbandingan daun sirih dan air mineral 1:2. Daun sirih yang sudah halus dimasukan ke dalam panci. Perebusan berlangsung 30 menit dengan suhu $100^{\circ} \mathrm{C}$. Setelah itu rebusan daun sirih diangkat dan disaring, dimasukan kedalam botol penyimpanan, akan menghasilkan dekok sebanyak $88,61 \%$, dekok daun sirih yang didapat merupakan dekok stok yang nantinya akan dilakukan pengenceran. Konsentrasi dekok daun sirih $40 \%$ dibuat dengan perbandingan $40 \mathrm{~mL}$ dekok stok ditambah 50 $\mathrm{mL}$ air (dibulatkan dari 48,61 mL), konsentrasi $50 \%$ dengan perbandingan $50 \mathrm{~mL}$ dekok stok ditambah $40 \mathrm{~mL}$ air (dibulatkan dari 38,61 $\mathrm{mL}$ ), konsentrasi $60 \%$ dengan perbandingan $60 \mathrm{~mL}$ dekok stok ditambah $30 \mathrm{~mL}$ air (dibulatkan dari 28,61 mL). Dekok daun sirih disimpan dalam botol tertutup. Sterilisasi alat untuk uji TPC (tabung reaksi, pipet berskala, corong kaca, pengaduk, dan botol sampel) menggunakan autoclaf selama 15 menit pada suhu $121^{\circ} \mathrm{C}$ dengan tekanan $15 \mathrm{lbs}$.

Pengambilan dan pengujian sampel $\mathrm{L}_{1} \mathrm{~S}_{0}$ : Sapi yang akan diperah dicuci ambing dan putingnya kemudian dikeringkan dengan menggunakan tisu. Pengambilan sampel dan pengujian dilakukan pagi hari (05:00 WIB) dan sore hari (17:00 WIB). Susu diambil sebanyak $\pm 2 \mathrm{~mL}$ per puting kemudian di tampung ke dalam masing-masing petri paddle. Uji CMT dilakukan segera setelah pengambilan sampel selesai. Susu diambil sebanyak $\pm 5 \mathrm{~mL}$ dimasukan ke dalam botol sampel yang telah diberi label sesuai perlakuan dan ulangan setelah pengujian CMT selesai. Sampel di simpan dalam termos yang telah diberi es dengan suhu $5^{\circ} \mathrm{C}-10^{\circ} \mathrm{C}$ lalu dibawa ke laboratorium untuk dilakukan uji TPC. Pengambilan dan pengujian sampel $\mathrm{L}_{2} \mathrm{~S}_{0}$ dan $\mathrm{L}_{3} \mathrm{~S}_{0}$ mengikuti prosedur sebelumnya.

Pengambilan dan pengujian sampel $\mathrm{L}_{1} \mathrm{~S}_{1}$ : Pengambilan sampel dan pengujian pada pukul (05:00 WIB). Sapi yang telah selesai diperah kemudian ambing dan putingnya dibersihkan menggunakan air dan dikeringkan menggunakan tisu. Keempat puting dicelupkan ke dalam botol teat dipping yang telah berisi dekok daun sirih $40 \%$ selama \pm 5 detik, pencelupan dilakukan sampai pada pangkal puting. Setelah \pm 12 jam, yaitu pada pukul (17:00 WIB), pengambilan sampel susu untuk uji CMT dan TPC mengikuti prosedur pengambilan dan pengujian sampel $\mathrm{L}_{1} \mathrm{~S}_{0}$ sebelumnya. Pengambilan dan pengujian sampel $\mathrm{L}_{1} \mathrm{~S}_{2}$ dan $\mathrm{L}_{1} \mathrm{~S}_{3}$ mengikuti prosedur sebelumnya, tetapi dekok daun sirih yang digunakan $50 \%$ dan $60 \%$. Pengambilan dan pengujian sampel $\mathrm{L}_{2} \mathrm{~S}_{1}, \mathrm{~L}_{2} \mathrm{~S}_{2}$ dan $\mathrm{L}_{2} \mathrm{~S}_{3}$ mengikuti prosedur sebelumnya, tetapi dekok daun sirih yang digunakan $40 \%, 50 \%$ dan $60 \%$. Pengambilan dan pengujian sampel $\mathrm{L}_{3} \mathrm{~S}_{1}, \mathrm{~L}_{3} \mathrm{~S}_{2}$, dan $\mathrm{L}_{3} \mathrm{~S}_{3}$ mengikuti prosedur sebelumnya, tetapi dekok daun sirih yang digunakan $40 \%, 50 \%$ dan $60 \%$.

Uji CMT: $2 \mathrm{~mL}$ diambahkan reagent CMT kedalam setiap petri paddle yang telah berisi sampel susu. Campuran tersebut kemudian digoyang-goyangkan membentuk lingkaran horizontal selama 10-15 detik. Perubahan yang terjadi diamati selama proses penggoyangan. Reaksi ini ditandai dengan ada tidaknya perubahan kekentalan pada susu, kemudian ditentukan berdasarkan skoring CMT.

Uji Total Plate Count: Pemeriksaan dilakukan dengan pengenceran desimal $10^{-1}$ sampai $10^{-5}$. Prosedur pengenceran $10^{-1}$ dilakukan dengan cara mengambil 1 $\mathrm{mL}$ sampel susu, masukan kedalam tabung reaksi berisi $9 \mathrm{~mL} \mathrm{NaCl}$ fisiologis kemudian 
Tabel 1. Tabel Dwi Arah Penurunan California Mastitis Test (CMT) pada Masing-masing Perlakuan selama Penelitian

\begin{tabular}{|c|c|c|c|c|c|c|}
\hline \multirow{2}{*}{ Laktasi (L) } & \multicolumn{4}{|c|}{ Sirih (\%) } & \multirow{2}{*}{ Total } & \multirow{2}{*}{ rata-rata } \\
\hline & $\mathrm{S}_{0}$ & $\mathrm{~S}_{1}$ & $\mathrm{~S}_{2}$ & $\mathrm{~S}_{3}$ & & \\
\hline $\mathrm{L}_{1}$ & 2,12 & 5,02 & 12,26 & 12,40 & 31,81 & 2,65 \\
\hline $\mathrm{L}_{2}$ & 2,12 & 5,02 & 12,28 & 13,04 & 32,46 & 2,70 \\
\hline $\mathrm{L}_{3}$ & 2,12 & 2,12 & 8,69 & 8,69 & 21,63 & 1,80 \\
\hline Total & 6,36 & 12,16 & 33,23 & 34,14 & 85,89 & \\
\hline rata-rata & 0,53 & 1,01 & 2,77 & 2,84 & & \\
\hline
\end{tabular}

dihomogenkan menggunakan stomacher. Pengenceran $10^{-2}$ dilakukan dengan cara memindahkan $1 \mathrm{~mL}$ larutan pengencer pada pengenceran $10^{-1}$ kedalam $9 \mathrm{~mL} \mathrm{NaCl}$ fisiologis menggunakan pipet berbeda kemudian dihomogenkan. Selanjutnya pengenceran dilakukan dengan cara yang sama untuk memperoleh pengenceran $10^{-3}$, $10^{-4}$, dan $10^{-5}$. Setelah pengenceran selesai, kemudian dilakukan pemupukan pada media nutrient agar. Pemupukan dilakukan pada pengenceran $10^{-3}, 10^{-4}$ dan $10^{-5}$. Pemupukan dilakukan dengan cara memasukkan $1 \mathrm{~mL}$ masing-masing pengenceran kedalam nutrient agar yang sudah diberi label sesuai dengan angka pengenceran. Setelah pemupukan selesai, nutrient agar dimasukan kedalam water bath untuk proses inkubasi selama 24 48 jam. Perhitungan jumlah bakteri dilakukan setelah 24-48 jam masa inkubasi dengan melakukan perhitungan jumlah koloni yang tumbuh dalam setiap nutrient agar. Prosedur perhitungan jumlah bakteri dapat dilakukan dengan prosedur yang digunakan. Metode penelitian menggunakan eksperimental dengan Rancangan Acak Lengkap Faktorial yang terdiri atas 12 perlakuan dan masingmasing diulang sebanyak 3 kali.

\section{HASIL DAN PEMBAHASAN}

\section{Pengaruh Perlakuan terhadap California Mastitis Test (CMT)}

CMT merupakan suatu cara mendeteksi adanya kejadian mastitis subklinis yang tidak bisa dilihat dengan kasat mata pada setiap putting susu sapi (Suriyasathaporn and Chupia, 2011). Rataan persentase penurunan California Mastitis Test (CMT) yang merupakan data hasil transformasi pada masing-masing perlakuan antara lain rataan persentase penurunan CMT terbesar ditunjukan pada $\mathrm{S}_{3}(2,84 \%)$, dan terendah pada perlakuan $\mathrm{S}_{0}(0,53 \%), \mathrm{S}_{1}(1,01 \%)$ dan $\mathrm{S}_{2}(2,77 \%)$, semakin tinggi persentase dekok daun sirih hijau yang digunakan semakin tinggi penurunan CMT. Penurunan CMT terbesar ditunjukan pada $\mathrm{L}_{2}(2,70 \%)$ terendah pada $\mathrm{L}_{3}(1,80 \%)$ dan $\mathrm{L}_{1}(2,65 \%)$ (Tabel 1).

Guna mengetahui pengaruh perlakuan terhadap persentase penurunan CMT, maka dianalisis dengan menggunakan sidik ragam. Hasil sidik ragam menunjukkan bahwa perlakuan berpengaruh sangat nyata $(\mathrm{P}<0,01)$ terhadap CMT dengan mengetahui pengaruh antar perlakuan dilanjutkan Uji Jarak Berganda Duncan's (Tabel 2).

Hasil Uji Jarak Berganda Duncan's menunjukkan rataan persentase penurunan CMT pada $\mathrm{S}_{3}$ nyata lebih besar jumlahnya dari rataan persentase penurunan CMT pada $\mathrm{S}_{2}, \mathrm{~S}_{1}$, dan $\mathrm{S}_{0}$ (Tabel 2). Rataan persentase penurunan CMT pada $S_{2}$ nyata lebih besar jumlahnya dari $\mathrm{S}_{1}$ dan $\mathrm{S}_{0}$. Hal ini diduga karena pada $\mathrm{S}_{3}(60 \%)$ persentase dekok daun sirih hijau yang digunakan lebih tinggi dibandingkan $\mathrm{S}_{2}(50 \%), \mathrm{S}_{1}(40 \%)$, dan $\mathrm{S}_{0} \quad(0 \%)$, sehingga kandungan senyawa antibakteri daun sirih hijau, yaitu minyak atsiri (fenilpropana, o-hidroksikavikol, kavikol, kavibetol, eugenol, metil engenol, 
Tabel 2. Hasil Uji Jarak Berganda Duncan's Pengaruh Perlakuan terhadap Persentase Penurunan California Mastitis Test (CMT)

\begin{tabular}{lcc}
\hline Perlakuan & Rataan Uji CMT (\%) & Signifikansi $(0,05)$ \\
\hline $\mathrm{S}_{0}$ & 0,53 & $\mathrm{a}$ \\
$\mathrm{S}_{1}$ & 1,01 & $\mathrm{a}$ \\
$\mathrm{S}_{2}$ & 2,77 & $\mathrm{~b}$ \\
$\mathrm{~S}_{3}$ & 2,84 & $\mathrm{~b}$ \\
\hline
\end{tabular}

Keterangan: Huruf yang berbeda pada kolom signifikansi menunjukkan berbeda nyata.

Tabel 3. Hasil Uji Jarak Berganda Duncan's Pengaruh Periode Laktasi terhadap Peresentase Penurunan California Mastitis Test (CMT)

\begin{tabular}{lcc}
\hline Perlakuan & Rataan Uji CMT (\%) & Signifikansi $(0,05)$ \\
\hline $\mathrm{L}_{3}$ & 1,80 & $\mathrm{a}$ \\
$\mathrm{L}_{2}$ & 2,70 & $\mathrm{a}$ \\
$\mathrm{L}_{1}$ & 2,65 & $\mathrm{a}$ \\
\hline
\end{tabular}

Keterangan: Huruf yang sama pada kolom signifikansi menunjukkan berbeda tidak nyata.

karvakrol, sineol, p-simol, terpinen, dan seskuiterpen) lebih banyak, akibatnya bekerja lebih efektif dalam menghambat masuknya bakteri kedalam lubang puting susu. Sesuai pendapat Nickerson (2013), mastitis terjadi melalui beberapa tahapan, yaitu kontak sejumlah mikroorganisme yang mengalami multiaplikasi di sekitar lubang puting, masuknya mikroorganisme akibat lubang puting yang terbuka, dan karena adanya luka. Tahap berikutnya, terjadi respon imun pada induk semang yang ditandai dengan berkumpulnya leukosit-leukosit untuk mengeliminasi mikroorganisme yang telah menempel pada sel-sel ambing, dengan adanya perlakuan teat dipping menggunakan cairan antiseptik, mencegah masuknya mikroorganisme ke dalam saluran ambing sehingga respon imun dari induk semang terhadap mikroorganisme tidak terjadi, yang mengakibatkan sel somatik menurun (Musnandar, 2011).

Rataan persentase penurunan CMT untuk $\mathrm{S}_{0}$ dan $\mathrm{S}_{1}$ serta $\mathrm{S}_{2}$ dan $\mathrm{S}_{3}$ berbeda tidak nyata, menunjukkan bahwa penggunaan dekok daun sirih hijau $0 \%$ dan $40 \%$ serta $50 \%$ dan $60 \%$ tidak begitu berpengaruh terhadap penurunan CMT. Hal ini diduga karena kandungan antibakteri dalam dekok daun sirih hijau belum mampu menghambat masuknya mikroorganisme kedalam saluran ambing.

Hasil Uji Jarak Berganda Duncan 's pada penurunan CMT untuk $\mathrm{L}_{1}, \mathrm{~L}_{2}$ dan $\mathrm{L}_{3}$ berbeda tidak nyata, menunjukkan bahwa periode laktasi tidak begitu berpengaruh terhadap penurunan CMT (Tabel 3). Hal ini diduga karena dekok daun sirih hijau merupakan cairan antibakteri yang digunakan di luar tubuh ternak sehingga tidak berpengaruh terhadap periode laktasi.

\section{Pengaruh Perlakuan terhadap Uji Total Plate Count (TPC) Air Susu Sapi}

TPC adalah menghitung total populasi mikroorganisme anaerob pada peralatan atau makanan (Sagitarini et al., 2013). Rataan uji TPC air susu sapi yang merupakan data hasil transformasi pada masing-masing perlakuan diantaranya rataan persentase penurunan $\mathrm{Uji}$ TPC pada air susu sapi terbesar ditunjukan pada $\mathrm{S}_{3}(4,63 \%)$ dan terendah pada $\mathrm{S}_{0}(0,53$ $\%), S_{1}(2,31 \%)$ dan $S_{2}(3,63 \%)$, semakin tinggi persentase dekok daun sirih hijau semakin besar penurunan jumlah bakterinya. Penurunan TPC pada air susu sapi terbesar 
Tabel 4. Tabel Dwi Arah Penurunan Total Plate Count (TPC) Air Susu Sapi pada Masing-masing Perlakuan selama Penelitian

\begin{tabular}{|c|c|c|c|c|c|c|}
\hline \multirow{2}{*}{ Laktasi (L) } & \multicolumn{4}{|c|}{ Sirih (\%) } & \multirow{2}{*}{ Total } & \multirow{2}{*}{ Rata-rata } \\
\hline & $\mathrm{S}_{0}$ & $\mathrm{~S}_{1}$ & $\mathrm{~S}_{2}$ & $\mathrm{~S}_{3}$ & & \\
\hline $\mathrm{L}_{1}$ & 2,12 & 10,36 & 13,13 & 17,37 & 42,98 & 3,58 \\
\hline $\mathrm{L}_{2}$ & 2,12 & 8,71 & 19,21 & 18,55 & 48,58 & 4,05 \\
\hline $\mathrm{L}_{3}$ & 2,12 & 8,64 & 11,21 & 19,61 & 41,57 & 3,46 \\
\hline Total & 6,36 & 27,71 & 43,54 & 55,53 & 133,14 & \\
\hline Rata-rata & 0,53 & 2,31 & 3,63 & 4,63 & & \\
\hline
\end{tabular}

Tabel 5. Hasil Uji Jarak Berganda Duncan ’s Pengaruh Perlakuan terhadap Peresentase Penurunan Total Plate Count (TPC)

\begin{tabular}{lcc}
\hline Perlakuan & Rataan Uji TPC (\%) & Signifikansi $(0,05)$ \\
\hline $\mathrm{S}_{0}$ & 0,53 & $\mathrm{a}$ \\
$\mathrm{S}_{1}$ & 2,31 & $\mathrm{a}$ \\
$\mathrm{S}_{2}$ & 3,63 & $\mathrm{~b}$ \\
$\mathrm{~S}_{3}$ & 4,63 & $\mathrm{c}$ \\
\hline
\end{tabular}

Keterangan: Huruf yang berbeda pada kolom signifikansi menunjukkan berbeda nyata.

ditunjukan pada $\mathrm{L}_{2}(4,05 \%)$ dan terendah pada $\mathrm{L}_{1}(3,58 \%)$ dan $\mathrm{L}_{3}(3,46 \%)$ (Tabel 4).

Guna mengetahui pengaruh perlakuan terhadap uji TPC dilakukan analisis sidik ragam. Hasil sidik ragam memperlihatkan bahwa perlakuan berpengaruh sangat nyata $(\mathrm{P}<0,01)$ terhadap uji TPC. Untuk mengetahui perbedaan antar perlakuan dilanjutkan Uji Jarak Berganda Duncan's, yang hasilnya menunjukkan rataan persentase penurunan bakteri dengan uji TPC air susu pada $\mathrm{S}_{3}$ nyata lebih besar jumlahnya dibandingkan rataan persentase penurunan bakteri pada $S_{2}, S_{1}$, dan $\mathrm{S}_{0}$ (Tabel 5). Hal ini diduga kandungan antibakteri dalam dekok daun sirih hijau yaitu minyak atsiri pada $\mathrm{S}_{3}$ lebih tinggi sehingga bekerja lebih efektif dalam membunuh bakteri disekitar ambing dan puting sapi, sedangkan $\mathrm{S}_{2}$ penurunan rataan persentase bakterinya lebih sedikit dari $\mathrm{S}_{3}$. Sesuai pendapat Kurniawan et al. (2013), daun sirih sama seperti daun kersen mengandung senyawa fenol sebagai senyawa antimikroba. Karlina et al. (2013), melaporkan bahwa secara kualitatif ekstrak etanol sirih hijau positif mengandung komponen aktif seperti alkaloid, tanin, fenolik dan steroid. Senyawa yang diduga berperan kuat sebagai senyawa antimikroba yaitu senyawa fenolik. Fenol adalah substansi yang mempunyai cincin aromatik dengan satu atau lebih gugus hidroksil yang dapat dibedakan dalam fenol sederhana dan asam fenol. Fenol dapat berperan sebagai racun bagi mikroba yaitu dengan menghambat aktivitas enzim, berikatan dengan gugus sulfhidril dan protein. Lebih lanjut Bhutto et al. (2012), flavonoid dapat berfungsi sebagai komponen antimikroba dengan membentuk ikatan komplek dengan dinding sel dan merusak membran.

Persentase penurunan jumlah bakteri dengan uji TPC pada $\mathrm{S}_{1}$ dan $\mathrm{S}_{0}$ berbeda tidak nyata, menunjukkan bahwa penggunaan dekok daun sirih hijau $40 \%$ dan $0 \%$ tidak begitu berpengaruh terhadap penurunan persentase bakteri, hal ini diduga kandungan antibakteri pada $\mathrm{S}_{1}$ dan $\mathrm{S}_{0}$ relatif sama, walaupun $\mathrm{S}_{0}$ tidak dilakukan pencelupan puting.

Hasil Uji Jarak Berganda Duncan's menunjukkan penurunan rataan persentase penurunan TPC untuk $\mathrm{L}_{1}, \mathrm{~L}_{2}$ dan $\mathrm{L}_{3}$ berbeda tidak nyata, menunjukkan bahwa periode 
Tabel 6. Hasil Uji Jarak Berganda Duncan's Pengaruh periode Laktasi terhadap Peresentase Penurunan Total Plate Count (TPC)

\begin{tabular}{lcc}
\hline Perlakuan & Rataan Uji TPC (\%) & Signifikansi $(0,05)$ \\
\hline $\mathrm{L}_{3}$ & 3,46 & $\mathrm{a}$ \\
$\mathrm{L}_{2}$ & 3,58 & $\mathrm{a}$ \\
$\mathrm{L}_{1}$ & 4,05 & $\mathrm{a}$ \\
\hline
\end{tabular}

Keterangan: Huruf yang berbeda pada kolom signifikansi menunjukkan berbeda nyata.

laktasi tidak begitu berpengaruh terhadap penurunan TPC (Tabel 6). Hal ini diduga karena dekok daun sirih hijau merupakan cairan antibakteri yang di gunakan di luar tubuh ternak sehingga tidak terpengaruh terhadap periode laktasi.

\section{KESIMPULAN}

Penggunaan dekok daun sirih hijau sebagai bahan teat dipping berpengaruh terhadap persentase penurunan California Mastitis Test dan jumlah bakteri pada susu pada Uji Total Plate Count, Penggunaan dekok daun sirih dosis $50 \%$ dan $60 \%$ menunjukkan hasil yang paling efektif dalam penurunan persentase CMT dan TPC. Serta Periode laktasi tidak berpengaruh nyata dalam penurunan persentase CMT dan jumlah total bakteri pada uji TPC.

\section{UCAPAN TERIMA KASIH}

Penulis mengucapkan terima kasih kepada kelompok peternak sapi perah di Kampung Areng Desa Cibodas Kecamatan Lembang Kabupaten Bandung Barat dan Laboratorium Mikrobiologi UPTD Balai Pelayanan Veteriner Cikole Lembang yang telah memfasilitasi kegiatan penelitian ini.

\section{DAFTAR PUSTAKA}

Bhutto, A. L., Murray, R. D. and Woldehiwet, Z. 2012. California mastitis test scores as indicators of subclinical intramammary infections at the end of lactation in dairy cows. Res. Vet. Sci. 92: 13-17.

Karlina C. Y., Ibrahim, M. dan Trimulyono G. 2013. Aktivitas antibakteri ekstrak herba krokot (Portulaca oleracea L.) terhadap Staphylococcus aureus dan Escherichia coli. E journal UNESA LenteraBio. 2 (1): 87-93.

Kurniawan, I., Sarwiyono, dan P. Surjowardojo, 2013. Pengaruh teat dipping menggunakan dekok daun kersen (Muntingia calibura L.) terhadap tingkat kejadian mastitis. Jurnal IlmuIlmu Peternakan 23: 27-31.

Musnandar, E. 2011. Efisiensi energi pada sapi perah Holstein yang diberi berbagai imbangan rumput dan konsentrat. Jurnal Penelitian Universitas Jambi Seri Sains 13: 53- 58.

Nickerson, S. 2013. Choosing the best teat dip for mastitis control and milk quality. Hill Farm Reseacrh Station. Louisiana State Univesity Agricultural Center. Homer, Loisiana.

Sagitarini, D., S. Usmiati, dan T. Astuti. 2013. Kadar protein dan nilai viskositas susu kambing Sapera di Cilacap dan Bogor. Jurnal Ilmiah Peternakan 1: 1057- 1063.

Suriyasathaporn, W. and V. Chupia. 2011. Reduction in number of bacteria after pre-milking teat dipping in milking dairy cows. J. Nat. Sci. 10: 301-306.

Surjowardojo, P. 2011. Tingkat kejadian mastitis dengan whiteside test dan produksi susu sapi perah Frisien Holstein. Jurnal Ternak Tropika 12: 4655. 
Utami, K., L. Radiati, dan P. Surjowardojo. 2014. Kajian kualitas susu sapi PFH (Studi kasus pada anggota KAN di Kecamatan Jabung Kabupaten Malang). Jurnal Ilmu-ilmu Ternak 24: 58-66.
Yusuf, R. 2010. Kandungan protein susu sapi perah friesian holstein akibat pemberian pakan yang mengandung tepung katu (Sauropus androgynus (L) (Merr) yang berbeda. Jurnal Teknologi Pertanian 6: 1-6. 